\title{
Effects of Pegylated Interferon Alpha and Ribavirin (pegIFN- $\alpha /$ RBV) Therapeutic Approach on Regulatory T Cells in HCV-Monoinfected and HCV/HIV-Coinfected Patients
}

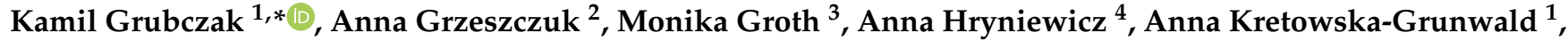 \\ Robert Flisiak $^{5}$ (D) and Marcin Moniuszko ${ }^{1,3, *}$
}

Citation: Grubczak, K.; Grzeszczuk, A.; Groth, M.; Hryniewicz, A.; Kretowska-Grunwald, A.; Flisiak, R.; Moniuszko, M. Effects of Pegylated Interferon Alpha and Ribavirin (pegIFN- $\alpha /$ RBV) Therapeutic Approach on Regulatory T Cells in HCV-Monoinfected and $\mathrm{HCV} / \mathrm{HIV}$-Coinfected Patients. Viruses 2021, 13, 1448. https:/ / doi.org/10.3390/v13081448

Academic Editor: Gilda Tachedjian

Received: 17 June 2021

Accepted: 20 July 2021

Published: 25 July 2021

Publisher's Note: MDPI stays neutral with regard to jurisdictional claims in published maps and institutional affiliations.

Copyright: (c) 2021 by the authors. Licensee MDPI, Basel, Switzerland. This article is an open access article distributed under the terms and conditions of the Creative Commons Attribution (CC BY) license (https:// creativecommons.org/licenses/by/ $4.0 /)$.
1 Department of Regenerative Medicine and Immune Regulation, Medical University of Bialystok, 15-269 Białystok, Poland; anna.kretowska-grunwald@umb.edu.pl

2 Department of Infectious Diseases and Neuroinfections, Medical University of Bialystok, 15-540 Bialystok, Poland; neuroin@umb.edu.pl

3 Department of Allergology and Internal Medicine, Medical University of Bialystok, 15-089 Bialystok, Poland; monika.groth@umb.edu.pl

4 Department of Rehabilitation, Medical University of Bialystok, 15-089 Bialystok, Poland; rehab@umb.edu.pl

5 Department of Infectious Diseases and Hepatology, Medical University of Bialystok, 15-540 Bialystok, Poland; robert.flisiak@umb.edu.pl

* Correspondence: kamil.grubczak@umb.edu.pl (K.G.); marcin.moniuszko@umb.edu.pl (M.M.); Tel./Fax: +48-85-748-59-72 (K.G. \& M.M.)

Abstract: Approximately 25\% of HIV-infected patients are co-infected with HCV. Notably, the burden of HCV infection (e.g., viral persistence, viral load, or HCV-related liver symptoms) is more pronounced in the presence of HIV co-infection. However, to date, the underlying immune mechanisms accounting for accelerated disease progression in HIV/HCV-coinfected individuals have not been described in sufficient detail. We hypothesized that regulatory $\mathrm{T}$ cells (Treg) bearing potent immunosuppressive capacities could not only play a substantial role in the pathogenesis of HCV/HIV coinfection but also modulate the response to the standard anti-viral therapy. Materials and Methods: To this end, we studied alterations in frequencies of Treg cells in correlation with other Treg-related and virus-related parameters in both $\mathrm{HCV}$ and $\mathrm{HCV} / \mathrm{HIV}$-infected patients subjected to standard pegIFN- $\alpha /$ RBV therapy. Results: Notably, we found that pegIFN- $\alpha /$ RBV therapy significantly increased levels of Treg cells in HCV-infected but not in HIV/HCV-coinfected individuals. Furthermore, $\mathrm{HIV} / \mathrm{HCV}$-coinfection was demonstrated to inhibit expansion of regulatory $\mathrm{T}$ cells during anti-viral treatment; thus, it might probably be responsible for viral persistence and HCV-related liver damage. Conclusions: Therapy with pegIFN- $\alpha /$ RBV demonstrated a significant effect on regulatory $\mathrm{T}$ cells in the course of HIV and/or HCV infection indicating a crucial role in the anti-viral immune response.

Keywords: pegIFN- $\alpha$ /RBV; HCV; HIV; HIV/HCV-coinfection; regulatory T cells

\section{Introduction}

Hepatitis C virus (HCV) and human immunodeficiency virus (HIV) coinfection affect approximately $25 \%$ of HIV-infected individuals. HIV coinfection constitutes around 3-5\% of all HCV-positive patients [1]. Clinical evidence has shown a higher rate of HCV viral persistence and increased viral load in $\mathrm{HCV} / \mathrm{HIV}$-coinfected patients compared to subjects with HCV monoinfection [2]. HIV infection is also associated with higher HCV RNA viral load and more rapid progression of HCV-associated liver diseases [3-5].

Mechanisms of accelerated disease progression in $\mathrm{HIV} / \mathrm{HCV}$-coinfection have not been fully determined. However, disturbances in virus-specific $\mathrm{T}$ cell responses via altered activity of regulatory $\mathrm{T}$ cells $\left(\mathrm{T}_{\mathrm{reg}}\right)$ are thought to play an important role [6-8] in infections caused by HIV, HCV, and herpes virus [9-12]. Prior work has shown $\mathrm{T}_{\text {reg }}$ expansion in the course of HIV and/or HCV infection [13-15]. Notably, several studies have indicated that 
$\mathrm{HIV} / \mathrm{HCV}$ coinfection may modify the immunomodulatory activities of these viruses as compared to monoinfection [16,17].

In both HCV-monoinfected and HCV/HIV-coinfected individuals, $\mathrm{T}_{\text {reg }}$ and other factors responsible for the induction of suppressive cells were found to play a crucial role in modulating $\mathrm{HCV}$-specific immune responses. $\mathrm{T}_{\text {regs }}$ are thought to exert their deleterious effects through excessive suppression of effector T cells in the antiviral response [18,19]. Approaches aimed at blocking the activity of $\mathrm{T}$ cells with a regulatory phenotype may improve antiviral immune responses [20] and protect from HCV-related complications such as liver fibrosis [21]. In this study, we focused on a $T_{\text {reg }}$ phenotype defined as $\mathrm{CD}^{+} \mathrm{CD} 25^{+} \mathrm{CD}_{127}{ }^{-} \mathrm{Foxp}^{+}$; however, considering the high correlation of $\mathrm{CD} 127$ with Foxp3, we also distinguished the $\mathrm{CD} 4^{+} \mathrm{CD} 25^{+} \mathrm{CD} 127^{-}$population as putative $\mathrm{T}_{\text {regs }}$ [22]. These phenotypes are mainly associated with immunosuppresive functions demonstrated by interaction with dendritic cells, the inhibition of effector lymphocytes, and the release of factors like IL-10, TGF-beta, and IL-35 [23].

Standard therapy in chronic HCV infection involved combined pegylated interferon alpha (pegIFN- $\alpha$ ) and ribavirin (RBV). Notably, prior work has indicated that pegIFN$\alpha / \mathrm{RBV}$ application in HCV/HIV-coinfected patients results in sustained HCV eradication in less than $40 \%$ of individuals [1]. Despite the introduction of direct-acting antivirals (DAA) in chronic HCV treatment, the established combined pegIFN- $\alpha /$ RBV therapy is still relevant $[24,25]$, especially in regions where there is a substantial risk of HIV coinfection [26].

Therefore, notwithstanding the beneficial therapeutic effects of pegIFN- $\alpha /$ RBV versus standard IFN- $\alpha / R B V$, further studies are needed to thoroughly evaluate pegIFN- $\alpha /$ RBV effectiveness and assess its utility in HCV-infected patients [27].

In this study, we aimed to assess the effects of combined pegIFN- $\alpha / R B V$ therapy on regulatory $\mathrm{T}$ cells and their association with immune system status and viral load in cohorts of $\mathrm{HCV}$-infected and $\mathrm{HCV} / \mathrm{HIV}$-coinfected participants. In addition, we evaluated the effects of $\mathrm{HIV} / \mathrm{HCV}$-coinfection on the suppressive activity of T cells and the anti-viral response.

\section{Materials and Methods}

\subsection{Patients}

In the experiment, we included three study groups: $\mathrm{HCV}$-infected patients $(n=11$; $55 \%$ male), HCV /HIV-coinfected patients ( $n=16 ; 69 \%$ male), and healthy individuals $(n=18 ; 56 \%$ male) as a control group.

Diagnosis of chronic HCV infection was defined as the presence of HCV RNA for more than 6 months measured by real-time PCR (Abbott RealTime PHCV, Champaign, IL, USA) (Lower Limit of Quantitation-LLQ, for HCV RNA was $12 \mathrm{IU} / \mathrm{mL}$ ) and positive results of anti-HCV antibodies measured by a third-generation enzyme immunoassay (Vitros ECI ${ }^{\circledR}$ : Ortho-Clinical Diagnostics, Rochester, NY, USA). HCV genotyping was evaluated using a commercial assay (Abbott RealTime HCV Genotype II). Plasma HIV RNA was measured using Versant HIV-1 RNA version 3 (Simens, Barcelona, Spain) (the limit of detection (LOD) for HIV RNA was 5 HIV-1 copies $/ \mathrm{mL}$ ). All patients were negative for hepatitis B surface antigen. In addition, peripheral blood samples were collected from patients before and after 6-12 months of anti-viral therapy consisting of pegylated interferon plus ribavirin (pegIFN$\alpha /$ RBV). Treatment included one dose of $180 \mathrm{mg}$ pegylated interferon alpha (pegIFN- $\alpha$ ) weekly (Pegasys ${ }^{\circledR}$; Hoffman-La Roche, Basel, Switzerland), combined with $1000 \mathrm{mg}$ of ribavirin (RBV) daily (Copegus ${ }^{\circledR}$; Hoffman-La Roche). HAART was maintained in subjects with HIV-coinfection; thus, effective control of its viral load was reported in patients enrolled in the study (Supplementary Table S1). Patients were recruited at the consultation point for HIV-infected and AIDS patients at the Department of Infectious Diseases and Hepatology, Medical University of Bialystok (Poland). The study was approved by the Local Ethics Committee, and written informed consent was obtained from all patients. 


\subsection{Peripheral Blood Mononuclear Cells (PBMC) Isolation}

Peripheral blood mononuclear cells (PBMC) were isolated by density gradient centrifugation using Ficoll (Amersham Biosciences, Piscataway, NJ, USA). Following isolation of the PBMC layer, two washing steps were performed with phosphate-buffered saline (PBS, Biomed Lublin, Poland). Viable cells were cryopreserved in fetal bovine serum (FBS, Gibco, Thermo Fisher, Carlsbad, CA, USA) with 10\% dimethyl sulfoxide (DMSO, Sigma-Aldrich, St. Louis, MO, USA) and stored in liquid nitrogen until flow cytometric analyses.

\subsection{Flow Cytometric Analysis}

Thawed peripheral blood mononuclear cells (approximately $0.5 \times 10^{6}$ cells) were stained with fluorochrome-conjugated monoclonal antibodies ( $5 \mu \mathrm{L}$ of each antibody) including: anti-CD4 FITC (clone RPA-T4), anti-CD25 PE-Cy5 (clone M-A251), and anti-CD127 AlexaFluor647 (clone HIL-7R-M21) (BD Bioscience, San Jose, CA, USA). Samples were incubated for $30 \mathrm{~min}$, at $4{ }^{\circ} \mathrm{C}$, in the dark, and then washed in PBS. Subsequently, cells were subjected to a 10-min permeabilization, in the dark, at room temperature (FACS Permeabilizing Solution 2; BD Bioscience, San Jose, CA, USA) to allow staining of intracellular markers. Samples were then washed with PBS and stained with $20 \mu \mathrm{L}$ of anti-Foxp3 PE (clone 259D/C7) (BD Bioscience, San Jose, CA, USA) monoclonal antibodies and incubated $30 \mathrm{~min}$, at $4{ }^{\circ} \mathrm{C}$, in the dark. Following incubation with antibodies, cells were washed in PBS and fixed (CellFIX; BD Bioscience, San Jose, CA USA). Flow cytometric data were acquired on FACS Calibur flow cytometer (BD Bioscience, San Jose, CA, USA) and analyzed using FlowJo (Tree Star, Ashland, OR, USA). CD4 ${ }^{+} \mathrm{T}$ lymphocytes were identified using a double-gating strategy of forward- and side-scatter identification in combination with high cellular CD4 expression. Foxp3-based identification of $\mathrm{T}_{\text {regs }}$ was performed within $\mathrm{CD} 4^{+}$lymphocytes and furthermore within more specific Treg population described as $\mathrm{CD}^{+} \mathrm{CD} 25^{+} \mathrm{CD} 127^{-}$cells (putative Tregs). The gating strategy was performed on the basis of unstained, FMO (fluorescence-minus-one), and negative population controls (Supplementary Figure S1).

\subsection{Statistical Analysis}

Statistical analysis was performed using GraphPad Prism 5.0 (GraphPad Software Inc., La Jolla, CA, USA). Assessment of the Gaussian data distribution was estimated with the use of Shapiro-Wilk and D'Agostino-Pearson normality tests. The normality distribution required confirmation with two independent tests, otherwise data were further tested with non-parametric tests. The Mann-Whitney test was used to compare healthy individuals, $\mathrm{HCV}$-infected, and HCV/HIV-coinfected patients. The analysis of differences before and after treatment was performed within each cohort using the Wilcoxon signed-rank test. Because of the lack of a Gaussian data distribution, mutual correlations between tested parameters were analyzed with the use of the nonparametric Spearman correlation test. Results are presented within tables and graphs as median values with 25th and 75th percentiles.

\section{Results}

Characteristics of the studied subjects based on immunological, biochemical, and virological laboratory results.

No significant differences were observed in routine laboratory tests results between the control group, $\mathrm{HCV}$-infected, and HCV/HIV-coinfected cohorts prior to pegIFN- $\alpha / \mathrm{RBV}$ based treatment. HCV-infected patients were clinically stable with no critical changes in, inter alia, liver function-related parameters, with only a slight increase in serum alanine aminotransferase (ALT) and gamma-glutamyl transferase (GGT). Furthermore, HCV / HIVcoinfected patients demonstrated adequate treatment-induced control of HIV viral load with a favorable level of $\mathrm{CD}^{+} \mathrm{T}$ cells in the blood and marginally elevated serum aspartate aminotransferase (AST), ALT, and GGT levels. Patients infected with HCV showed a significantly lower score for the AST-to-platelet ratio index (APRI) compared to HCV/HIV- 
coinfected patients, suggesting a higher risk of hepatic fibrosis in the latter group of patients. Moreover, $\mathrm{HCV}$ /HIV-coinfected patients had a lower HCV viral load compared to subjects with HCV-monoinfection (Supplementary Table S1).

3.1. Alterations in Frequencies and Absolute Numbers of Regulatory T Cells in HCV-Infected and HCV/HIV-Coinfected Patients in the Course of Anti-Retroviral Therapy

We found that both HCV-infected and HCV/HIV-coinfected patients had significantly higher frequencies of regulatory cells, namely, $\mathrm{CD} 4^{+} \mathrm{Foxp} 3^{+}$and $\mathrm{CD} 4^{+} \mathrm{CD} 25^{+} \mathrm{CD} 127^{-} \mathrm{Foxp} 3^{+}$ $\mathrm{T}$ cells, compared to the control group. Interestingly, standard antiviral treatment resulted in a significant increase in these populations in patients with HCV infection, whereas no changes were observed in the HCV/HIV-coinfected group (Figure 1a,c). Comparable alterations were found in the suppressive potential within $\mathrm{CD} 4^{+} \mathrm{CD} 25^{+} \mathrm{CD} 127^{-}$cells based on Foxp3 expression (Figure 1b). We did not observe any changes in the frequency of putative $\mathrm{CD}^{+} \mathrm{CD} 25^{+} \mathrm{CD} 127^{-}$regulatory T cells in $\mathrm{HCV}$-infected patients (Figure 1d) (Supplementary Table S2).

Analysis of $\mathrm{CD} 4^{+} \mathrm{CD} 25^{+} \mathrm{CD} 127^{-}{ }^{-}$oxp $3^{+}$cells confirmed that HCV-infected and HCV/ HIV-coinfected patients have a greater number of regulatory cells. However, no differences were found in reference to $\mathrm{CD} 4^{+} \mathrm{Foxp} 3^{+}$cells. Furthermore, antiretroviral therapy led to a decline in $\mathrm{CD}^{+}{ }^{+} \mathrm{Foxp}^{+}{ }^{+}$cell counts in $\mathrm{HCV} / \mathrm{HIV}$-coinfected patients, and unlike frequencies, absolute numbers of $\mathrm{CD} 4^{+} \mathrm{CD} 25^{+} \mathrm{CD} 127^{-} \mathrm{Foxp}^{+} \mathrm{T}$ cells remained unchanged in the course of treatment (Figure 2a,b). Similarly, changes in putative $\mathrm{CD} 4^{+} \mathrm{CD} 25^{+} \mathrm{CD} 127^{-}$cells were in accordance with $\mathrm{CD} 4^{+} \mathrm{CD} 25^{+} \mathrm{CD} 127^{-}$Foxp $3^{+}$cell number, however, with significantly lower levels following antiretroviral therapy in both groups (Figure 2c). Interestingly, we found that pegIFN- $\alpha /$ RBV administration in HCV-infected patients led to a slight decrease in the total number of $\mathrm{CD} 4^{+} \mathrm{T}$ cells. In HCV/HIV-coinfected patients, antiviral therapy exacerbated the expansion of $\mathrm{CD}^{+}$lymphocytes (Figure 2d) (Supplementary Table S2).

\subsection{Effects of Anti-Viral Therapy on T Cell Activation- (CD25) and Development-Associated Protein (CD127) in HCV-Infected and HCV/HIV-Coinfected Patients}

We did not find any significant differences in the frequency of $C D 25^{+} \mathrm{T}$ cells in the experimental groups compared to the control, with only a slight increase in HCV/HIVcoinfected patients. However, mean fluorescent intensity of CD25 was greater following antiretroviral drug exposure in HCV-infected and HCV/HIV-coinfected individuals (Figure 3a,b). In reference to CD127 expression, both frequency and MFI were lower in patients with monoinfection or coinfected with HIV before treatment and remained unchanged in response to treatment (Figure 3c,d) (Supplementary Table S2).

\subsection{Variations in Regulatory T Cells Frequencies and Absolute Numbers among HCV-Infected and HCV/HIV-Coinfected Patients Considering Genotype of Hepatitis C Virus}

Considering the different genotypes of the hepatitis $C$ virus, there were no observable differences in $\mathrm{CD}^{+} \mathrm{Foxp}^{+}$phenotype in terms of both frequency and absolute cell count (Figure $4 \mathrm{a}$,e). Furthermore, analysis of $\mathrm{CD}^{+} \mathrm{CD} 25^{+} \mathrm{CD} 127^{-}$Foxp $3^{+}$cells indicated that patients infected with $\mathrm{HCV}$ types 1 and 3 demonstrate an increased absolute number of these cells. This was additionally noted in all three studied $\mathrm{HCV}$ genotypes of $\mathrm{HCV} / \mathrm{HIV}$ coinfected individuals. Frequencies of $\mathrm{CD} 4^{+} \mathrm{CD} 25^{+} \mathrm{CD} 127^{-} \mathrm{Foxp} 3^{+}$seem to correspond to these results; however, a significant difference was observed only in HCV/HIV-coinfected patients with HCV type 3 (Figure 4c,f). Similarly, the frequency of immunosuppressive Foxp $3^{+}$phenotype within regulatory $\mathrm{T}$ cells was found to be higher only in coinfected patients with the HCV type 4 genotype (Figure $4 \mathrm{~b}$ ). In reference to the putative regulatory $\mathrm{CD} 4{ }^{+} \mathrm{CD} 25^{+} \mathrm{CD} 127^{-}$phenotype, results were in accordance with absolute numbers of $\mathrm{CD} 4{ }^{+} \mathrm{CD} 25^{+} \mathrm{CD} 127^{-}$Foxp $^{+}$cells, with a lack of difference only in $\mathrm{HCV} / \mathrm{HIV}$-coinfected individuals with the HCV type 3 infection. Frequency analysis of $\mathrm{CD} 4^{+} \mathrm{CD} 25^{+} \mathrm{CD} 127^{-}$cells, however, showed higher values only in HCV type 3 patients with coinfection (Figure $4 \mathrm{~d}, \mathrm{~g}$ ). In addition, we demonstrated significantly lower absolute numbers of $\mathrm{CD}^{+}$cells in $\mathrm{HCV}$ - 
infected patients with HCV type 1 and HCV type 3 in HCV/HIV-coinfected subjects (Figure $4 \mathrm{~h}$ ).
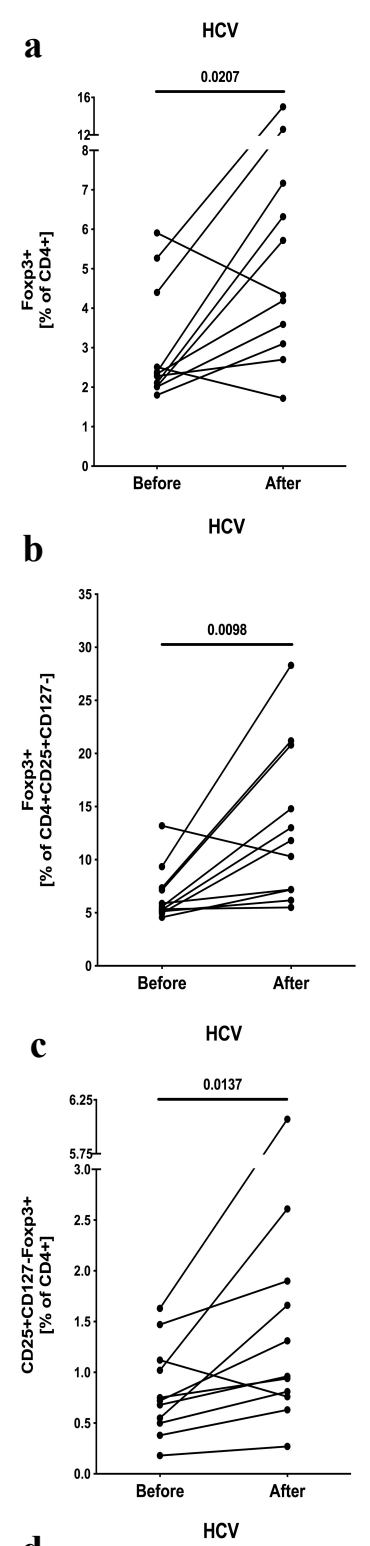

d

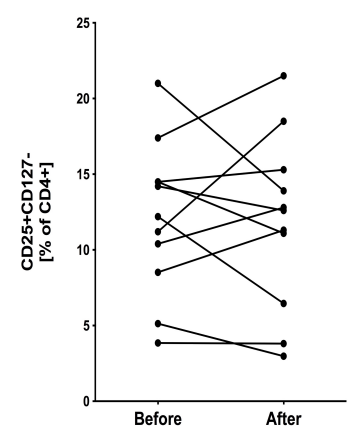

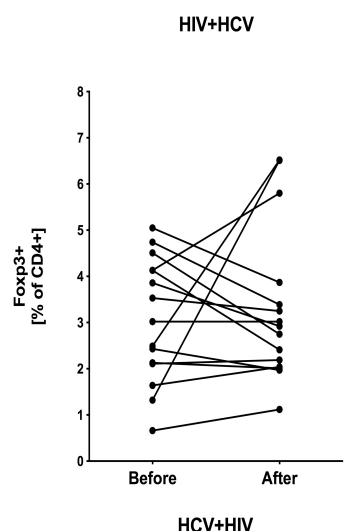
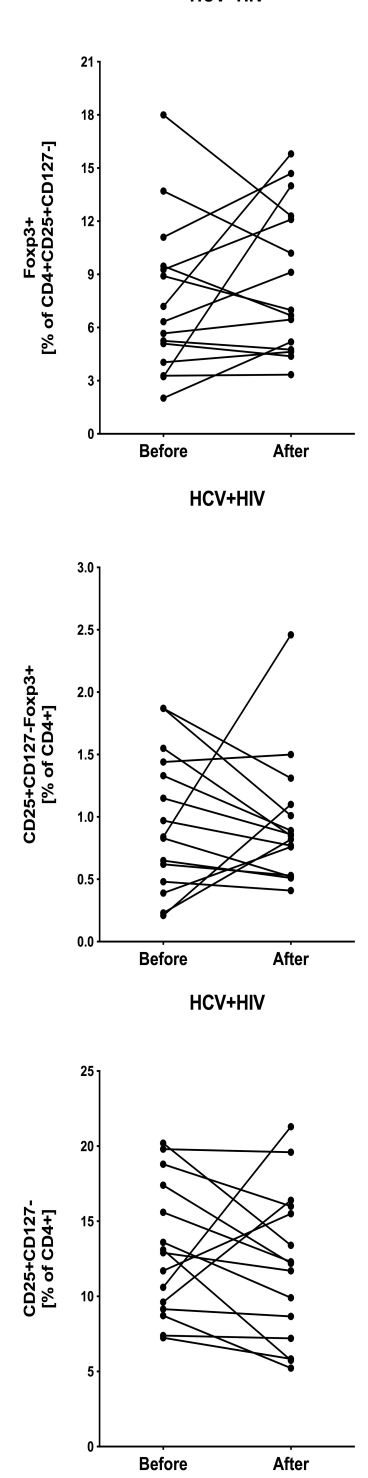
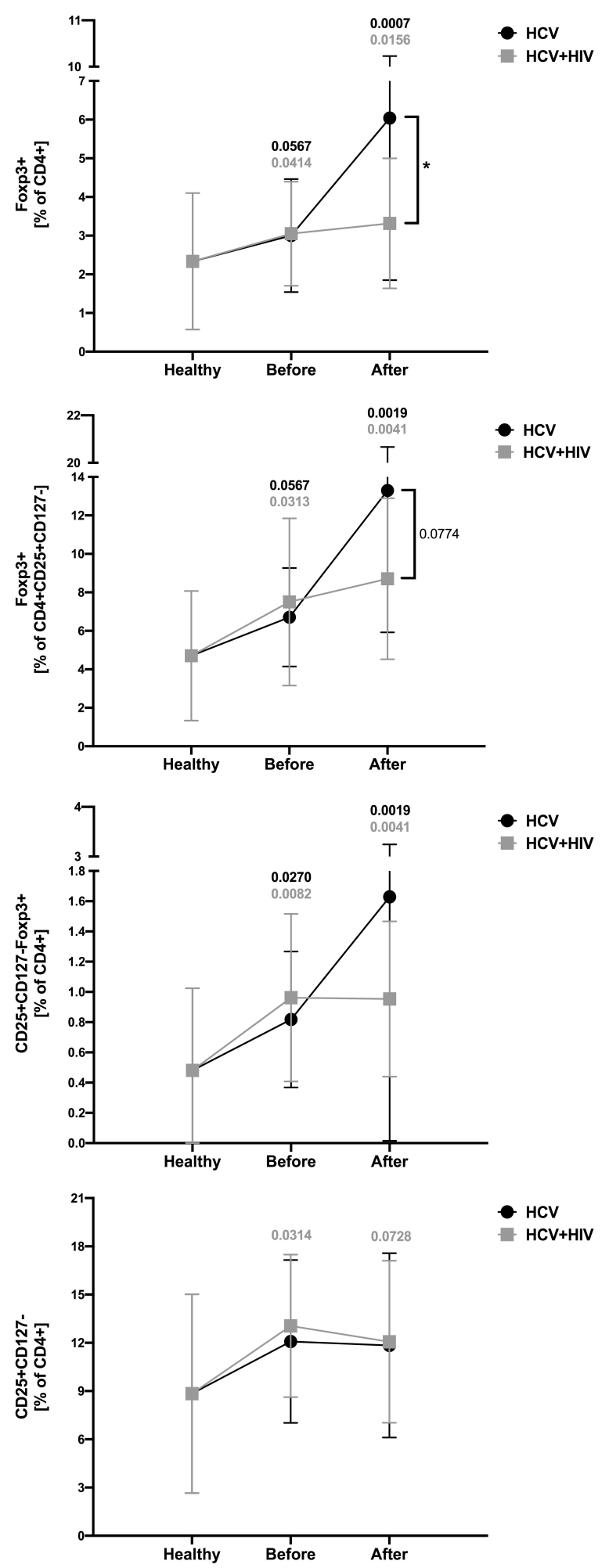

Figure 1. Frequencies of regulatory T cells in HCV-infected (left column) and HCV/HIV-coinfected (right column) patients in the course of anti-viral therapy. Data presenting the effects of therapy and differences between studied groups in the course of treatment in relation to healthy control subjects. Treg-related parameters included: Foxp3-positive cells within $\mathrm{CD}^{+}(\mathbf{a})$ and $\mathrm{CD} 4^{+} \mathrm{CD} 25^{+} \mathrm{CD} 127^{-}$lymphocytes (b), frequency of $\mathrm{CD} 25^{+} \mathrm{CD} 127^{-} \mathrm{Foxp}^{+}(\mathbf{c})$ and $\mathrm{CD} 25^{+} \mathrm{CD} 127^{-}$(d) in pool of $\mathrm{CD} 4^{+} \mathrm{T}$ cells. 

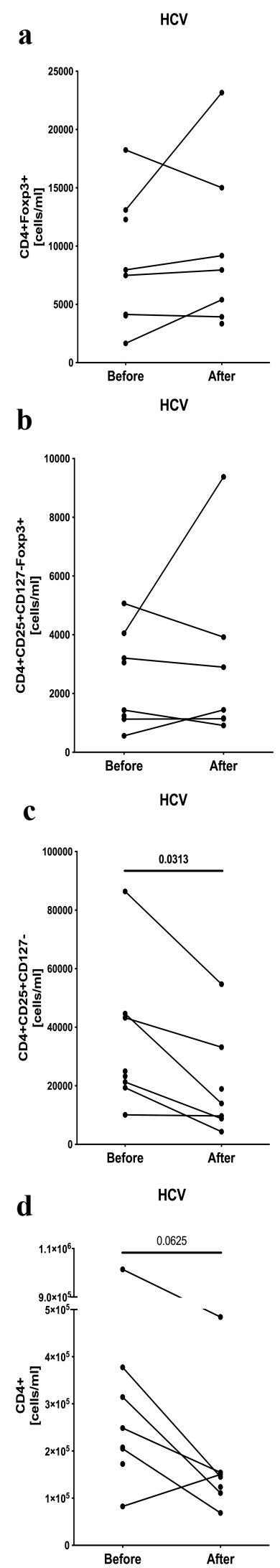
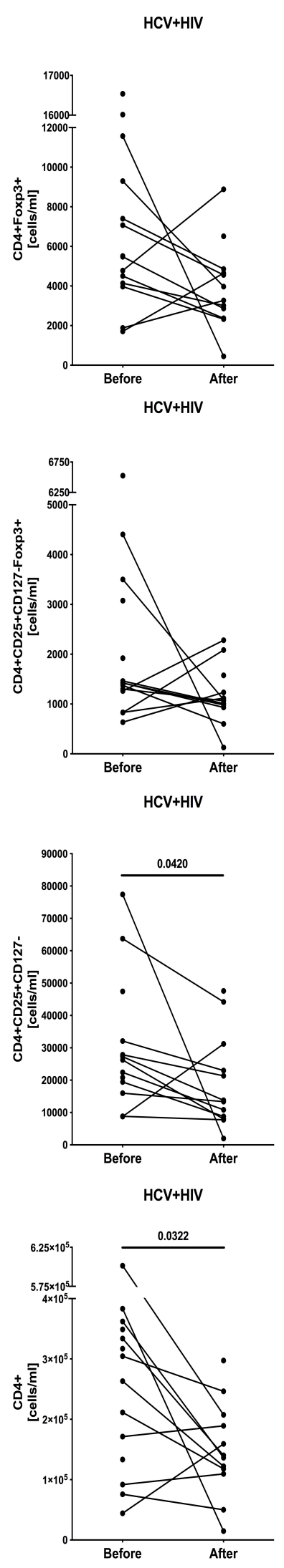
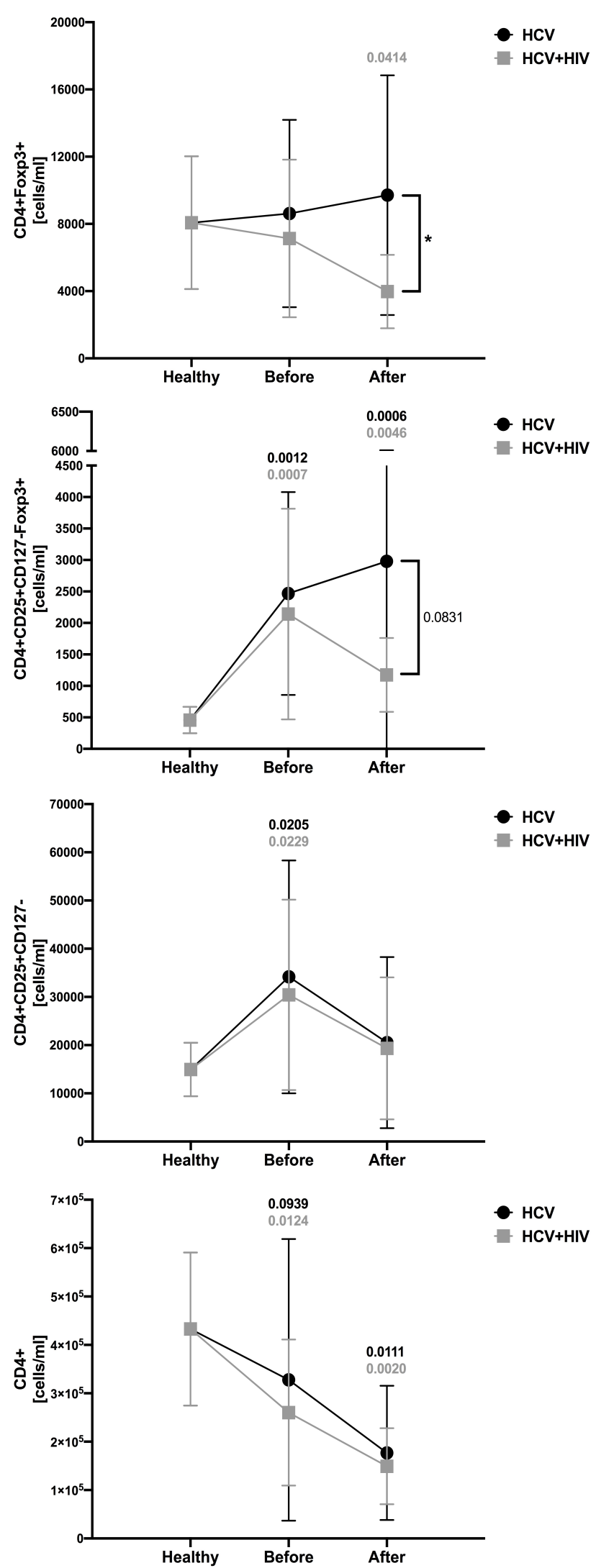

Figure 2. Anti-viral treatment effects on regulatory T cells absolute numbers in HCV-infected (left column) and HCV/HIVcoinfected (right column) patients. Data presenting the effects of therapy and differences between studied groups in the course of treatment in relation to healthy control subjects. Treg-related parameters included: $\mathrm{CD}^{+} \mathrm{Foxp}^{+}(\mathbf{a})$, $\mathrm{CD} 4^{+} \mathrm{CD} 25^{+} \mathrm{CD} 127^{-} \mathrm{Foxp}^{+}(\mathbf{b}), \mathrm{CD} 4^{+} \mathrm{CD} 25^{+} \mathrm{CD} 127^{-}(\mathbf{c})$, and total $\mathrm{CD} 4^{+}$(d) lymphocytes. 


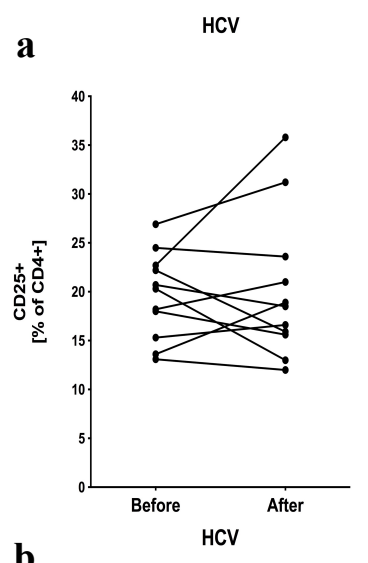

b
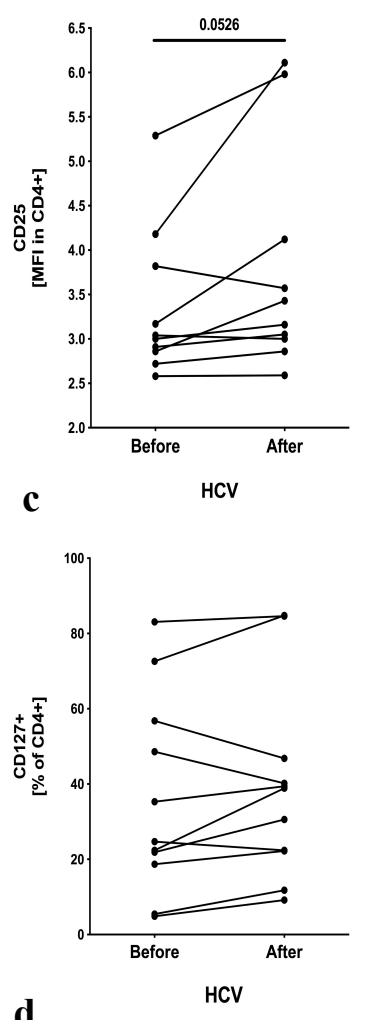

d

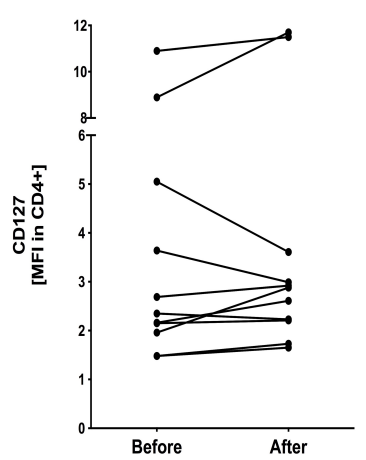

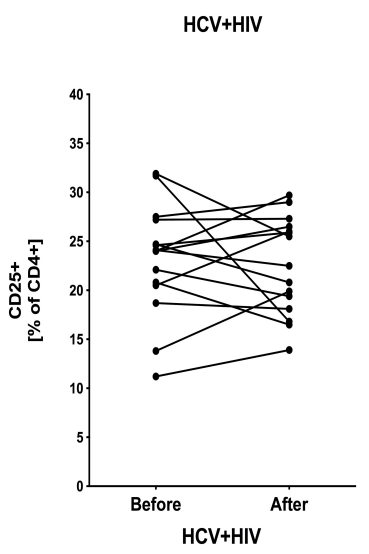
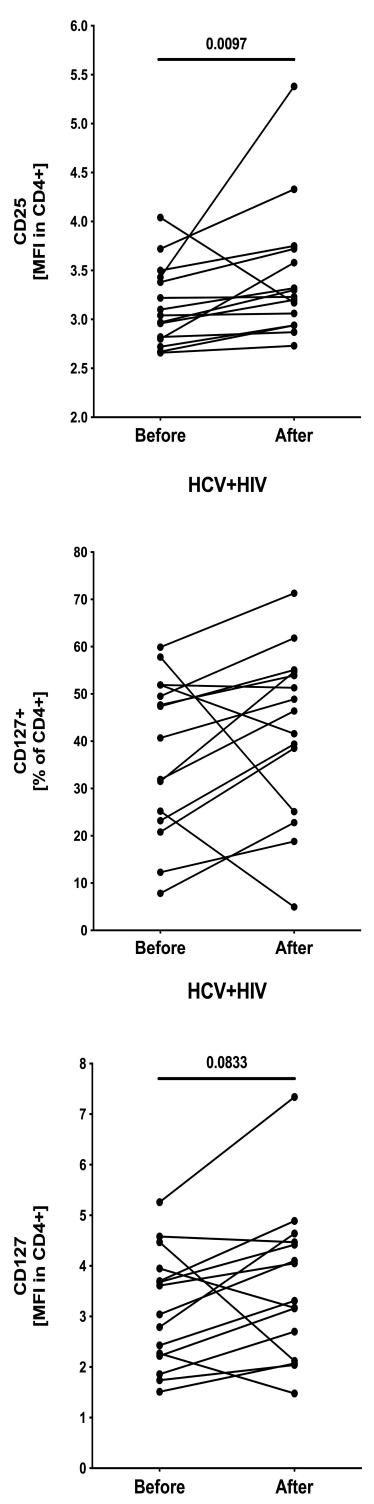
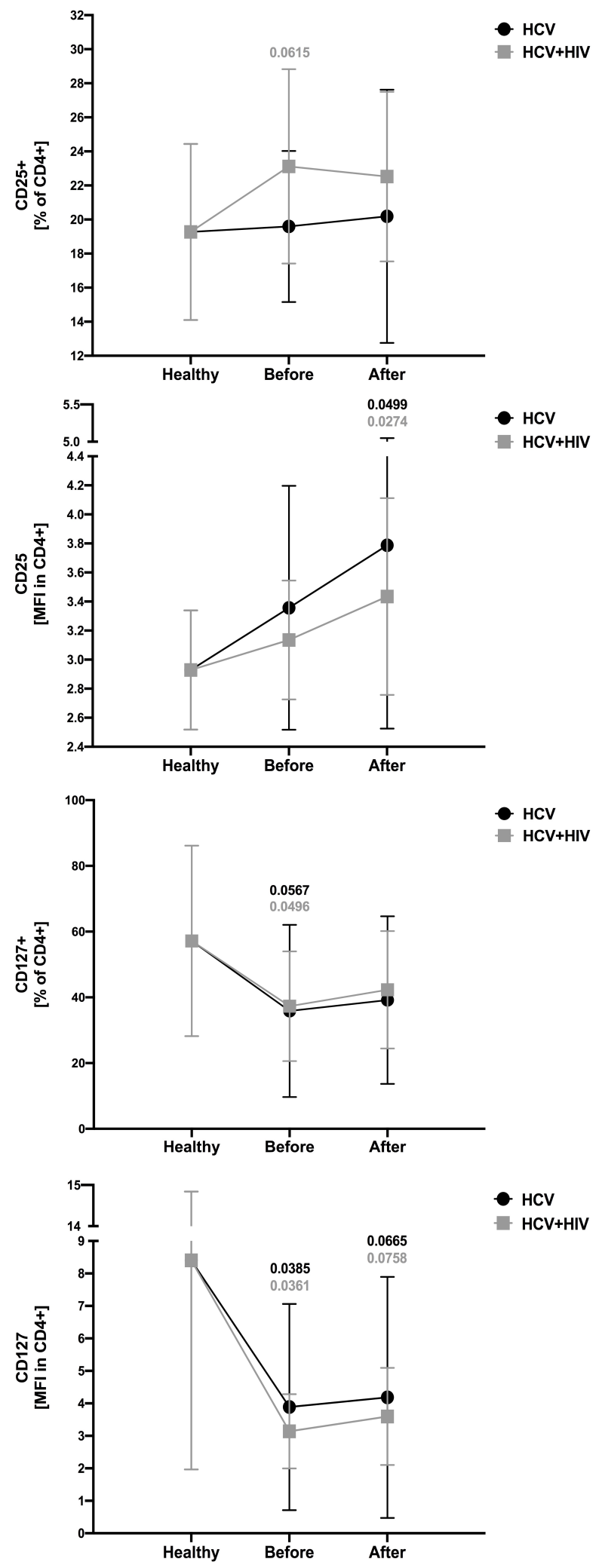

Figure 3. Alterations in T cells activation- (CD25) and development-related (CD127) proteins in the course of anti-viral treatment of HCV-infected and HCV/HIV-coinfected patients. Data presenting effects of therapy and differences between studied groups in the course of treatment in relation to healthy control subjects. CD25 activation marker was analyzed as frequency (a) and mean fluorescence intensity (MFI) (b) within CD4 $4^{+}$lymphocytes, and similarly, CD127 was demonstrated as frequency of marker-positive cells (c) and MFI (d) in $\mathrm{CD}^{+} \mathrm{T}$ cell pool. 

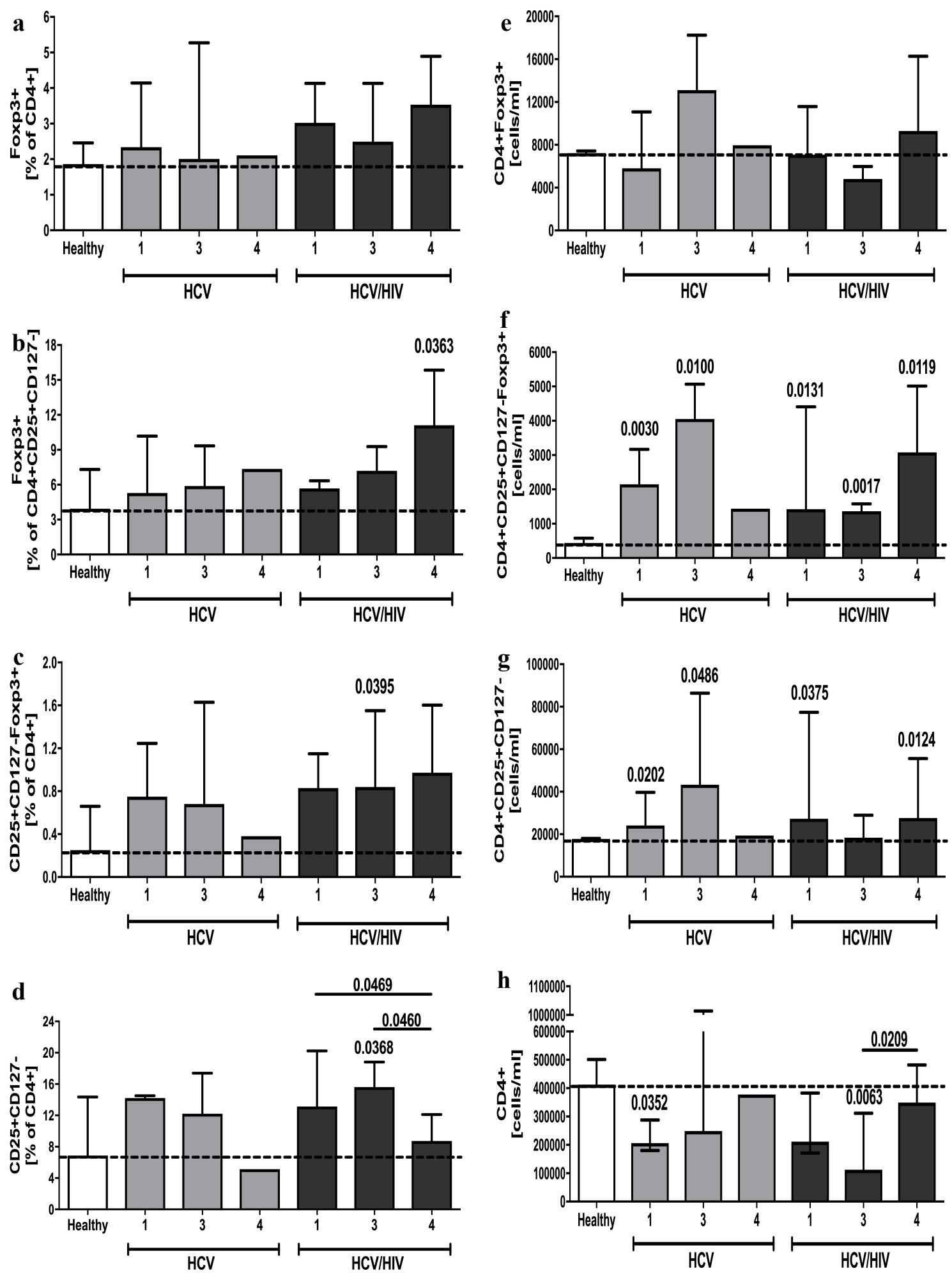

Figure 4. HCV virus genotype effects on frequency and absolute numbers of regulatory $\mathrm{T}$ cells in HCV-infected and $\mathrm{HCV} / \mathrm{HIV}$-coinfected patients. Treg-related parameters analyzed in context of frequencies: Foxp3 ${ }^{+}$in $\mathrm{CD} 4^{+}(\mathbf{a})$ and $\mathrm{CD}^{+} \mathrm{CD} 25^{+} \mathrm{CD} 127^{-} \mathrm{T}$ cells $(\mathbf{b}), \mathrm{CD} 25^{+} \mathrm{CD} 127^{-} \mathrm{Foxp}^{+}$(c) and $\mathrm{CD} 25^{+} \mathrm{CD} 127^{-}$(d) within $\mathrm{CD} 4^{+} \mathrm{T}$ cell pool; and absolute numbers: Foxp3 ${ }^{+}$(e), CD25 ${ }^{+} \mathrm{CD} 127^{-}$Foxp3 $^{+}$(f), CD25 ${ }^{+} \mathrm{CD} 127^{-}$(g) CD4 $4^{+}$lymphocytes, and total CD4 ${ }^{+}$cells (h). Significant changes in relation to healthy controls indicated directly above specific group column; additional differences distinguished with lines connecting significantly different groups. 
3.4. Hepatitis C Virus Genotype Influence on Differential Response of Regulatory T Cells to Anti-Viral Treatment of HCV-Infected and HCV/HIV-Coinfected Patients

When analyzing the effects of treatment on frequencies of $\mathrm{CD}^{+} \mathrm{Foxp}^{+}$cells, we found increased values only in HCV-infected patients with HCV types 1 and 3 (Figure 5a). However, individuals coinfected with HCV types 1 or 3 and HIV demonstrated even lower levels of absolute $\mathrm{CD}^{+}{ }^{+}$Foxp $^{+}$cell numbers in response to antiretroviral therapy (Figure 6a). In reference to the $\mathrm{CD} 4^{+} \mathrm{CD} 25^{+} \mathrm{CD} 127^{-}$Foxp3 $3^{+}$phenotype, a similar data distribution was observed compared to $\mathrm{CD}^{+} \mathrm{Foxp}^{+}$frequencies in $\mathrm{HCV}$-infected patients. Moreover, here we also demonstrated higher values, which remained unchanged despite treatment, of these cells in $\mathrm{HCV} / \mathrm{HIV}$-coinfected subjects with HCV type 3 (Figure $5 \mathrm{c}$ ). Considering absolute numbers of $\mathrm{CD} 4^{+} \mathrm{CD} 25^{+} \mathrm{CD} 127^{-}$Foxp $3^{+}$cells, patients infected with HCV types 1 and 3 only showed higher initial levels of these cells and did not respond to this therapeutic approach. In $\mathrm{HCV} / \mathrm{HIV}$-coinfected individuals, all three types of HCV demonstrated higher values of the regulatory phenotype, with a presumed decline in patients with HCV types 1 and 4 following antiretroviral therapy (Figure 6b). Interestingly, treatment application in $\mathrm{HCV}$-infected subjects led to an increase in the immunosuppressive Foxp $3^{+}$ phenotype within $\mathrm{CD} 4^{+} \mathrm{CD} 25^{+} \mathrm{CD} 127^{-}$cells in patients with $\mathrm{HCV}$ types 1,3 , and probably 4 (despite a lack of significance associated with the small sample size). In reference to $\mathrm{HCV} / \mathrm{HIV}$-coinfected patients, significantly higher values in HCV type 4 patients remained unchanged in response to anti-retroviral therapy (Figure 5b). No significant differences were found in $\mathrm{HCV}$-infected individuals in regards to $\mathrm{CD} 4{ }^{+} \mathrm{CD} 25^{+} \mathrm{CD} 127^{-}$phenotype frequencies, with higher levels not responding to treatment in $\mathrm{HCV} / \mathrm{HIV}$-coinfected patients with HCV type 3 (Figure $5 \mathrm{~d}$ ). Absolute $\mathrm{CD} 4^{+} \mathrm{CD} 25^{+} \mathrm{CD} 127^{-}$cell number analysis revealed increased values in HCV-infected patients with HCV types 1 and 3, with only type 1 responding to therapy, and a non-significant decline in those infected with HCV type 4. In HCV/HIV-coinfected subjects, individuals infected with HCV types 1 and 4 demonstrated higher levels of putative regulatory $\mathrm{T}$ cells, which decreased (albeit insignificantly) following antiretroviral therapy (Figure 6c). The therapeutic approach seemed to have caused a crucial decline in total $\mathrm{CD}^{+}$cell number only in patients infected with $\mathrm{HCV}$ type 4, both in HCV-infected and HCV / HIV-coinfected individuals (Figure 6d).

\subsection{Association between Regulatory T Cells and Immunological, Biochemical and Virological Laboratory Parameters, in HCV-Infected and HCV/HIV-Coinfected Patients}

In $\mathrm{HCV}$-infected patients, we found a negative correlation in $\mathrm{CD}^{+} \mathrm{Foxp}^{+}$absolute cell number and HCV viral load prior to treatment. This population of cells, as well as the absolute number of $\mathrm{CD} 4^{+} \mathrm{CD} 25^{+} \mathrm{CD} 127^{-}$Foxp $3^{+}$cells, demonstrated a positive correlation with serum $\mathrm{CD} 4^{+}$lymphocyte levels. The frequency of putative $\mathrm{CD} 4^{+} \mathrm{CD} 25^{+} \mathrm{CD} 127^{-} \mathrm{T}$ cells was found to correlate negatively with CD127 expression within the CD4 ${ }^{+}$cell population. No correlations were observed between regulatory $\mathrm{T}$ cells and biochemical parameters related to liver damage, namely, AST, ALT and GGT. When analyzing association between treatment-related change in Treg parameters and other factors, correlations with HGB, $\mathrm{CD}^{+}$, and $\mathrm{CD}^{+} \mathrm{CD}^{+} 5^{+}$cells level were maintained. In addition, changes in Treg-associated parameters correlated significantly with AST, ALT, and GGT (Supplementary Figure 2).

The numbers of $\mathrm{CD}^{+} \mathrm{Foxp}^{+}$regulatory T cells were found to correlate positively with the HIV viral load in untreated HCV/HIV-coinfected subjects. As regards the HCV RNA level, the frequency of Foxp $3^{+}$cells within the $\mathrm{CD} 4{ }^{+} \mathrm{CD} 25^{+} \mathrm{CD} 127^{-}$population showed a positive correlation; however, the absolute number of putative $\mathrm{CD} 4^{+} \mathrm{CD} 25^{+} \mathrm{CD} 127^{-}$ regulatory $\mathrm{T}$ cells demonstrated a negative correlation with the HCV viral load. Similarly to $\mathrm{HCV}$-infected patients, a regulatory $\mathrm{T}$ cell-related parameter, absolute $\mathrm{CD} 4^{+} \mathrm{CD} 25^{+} \mathrm{CD} 127^{-}$ cell number, correlated positively with levels of $\mathrm{CD}^{+} \mathrm{T}$ cells in $\mathrm{HCV} / \mathrm{HIV}$-coinfected individuals. Additionally, a negative correlation was found in relation to the frequency of $\mathrm{CD}^{+} \mathrm{CD}^{2} 5^{+} \mathrm{CD} 127^{-}$Foxp3 $^{+}$and putative $\mathrm{CD} 4^{+} \mathrm{CD} 25^{+} \mathrm{CD} 127^{-}$cells. Despite a lack of correlation between regulatory T cells and AST, ALT, or GGT, we observed a positive link between putative $\mathrm{CD} 4^{+} \mathrm{CD} 25^{+} \mathrm{CD} 127^{-}$regulatory cells and the parameter associated with hepatic fibrosis-APRI. Furthermore, in the context of change in Treg-related parameters 
and their correlation with other studied factors, associations have been maintained in reference to $\mathrm{PLT}, \mathrm{CD} 4^{+}$, and $\mathrm{CD} 4^{+} \mathrm{CD} 25^{+}$cells. As observed in $\mathrm{HCV}$ patients, a correlation with ALT also appeared (Supplementary Figure S3).

\section{HCV-infected}
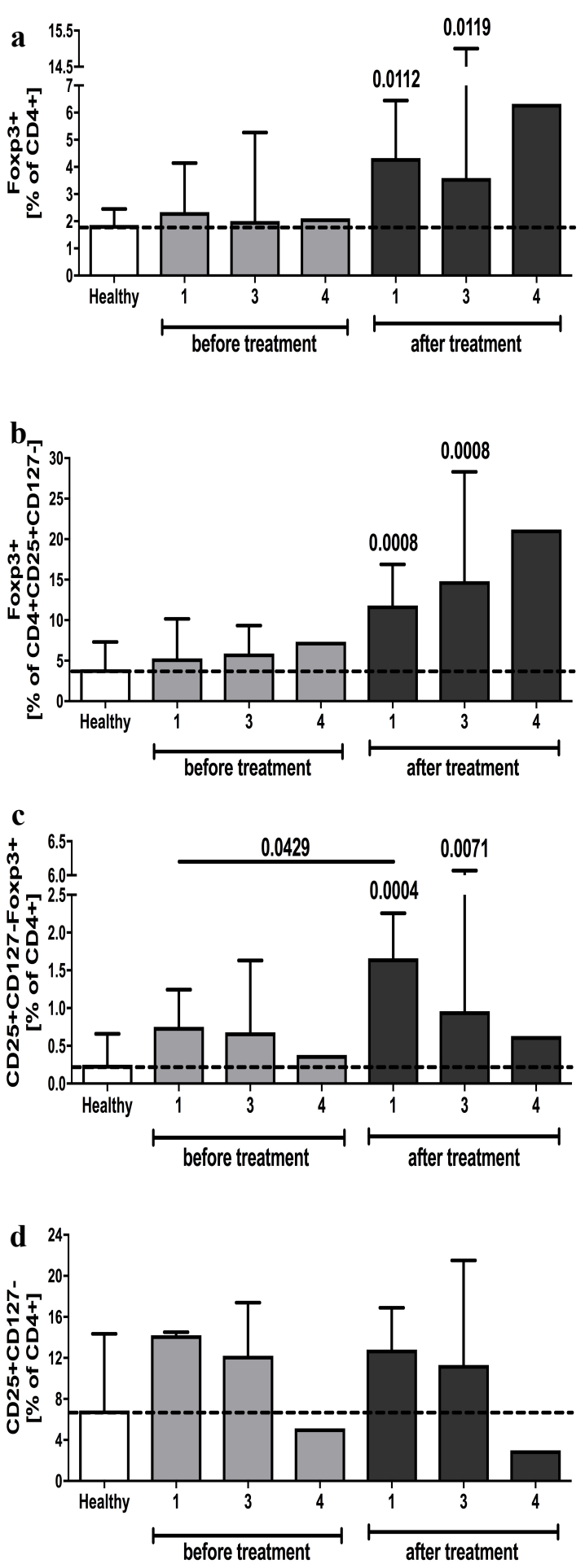

\section{HCV/HIV-coinfected}
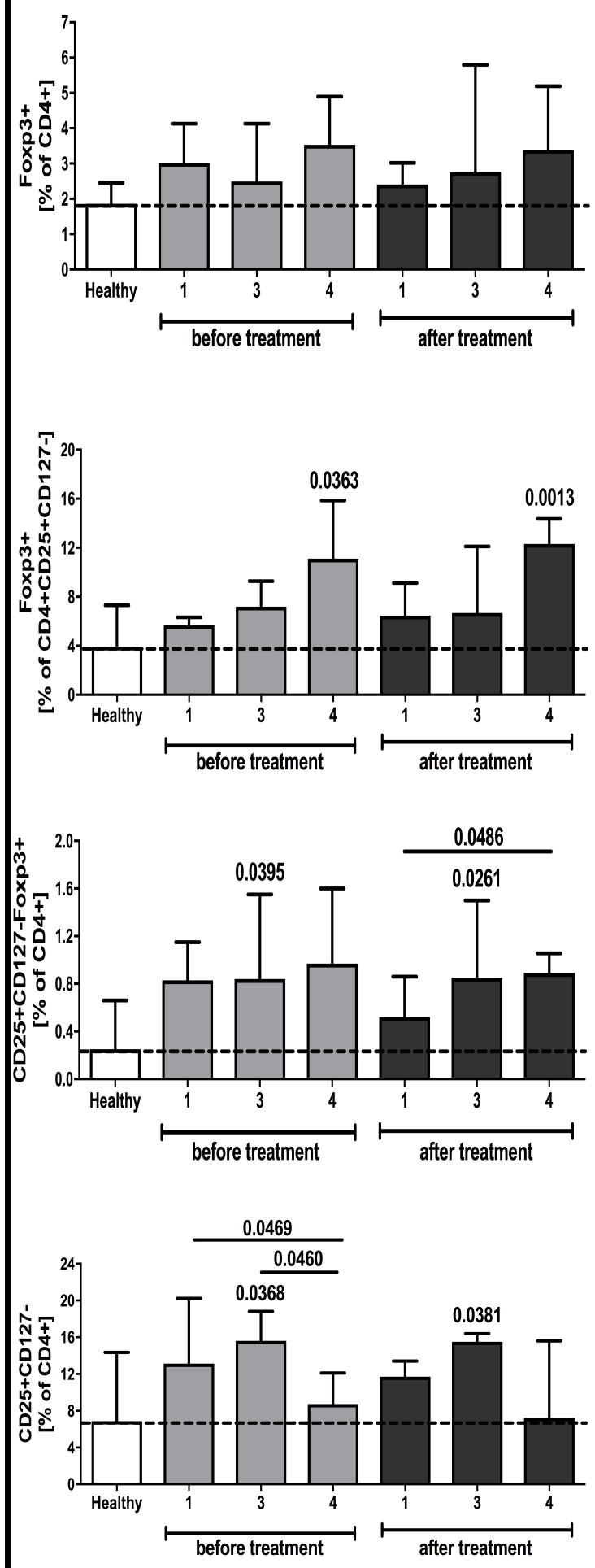

Figure 5. HCV virus genotype-related differences in regulatory $\mathrm{T}$ cells frequencies in response to anti-viral therapy in $\mathrm{HCV}$-infected (left column) and HCV/HIV-coinfected patients (right column). Data related to T regs in HCV or HCV/HIVcoinfected patients presented as: Foxp3 ${ }^{+}$in $\mathrm{CD}^{+}(\mathbf{a})$ and $\mathrm{CD} 4{ }^{+} \mathrm{CD} 25^{+} \mathrm{CD} 127^{-}$(b) lymphocytes, $\mathrm{CD} 25^{+} \mathrm{CD} 127^{-} \mathrm{Foxp}^{+}(\mathbf{c})$ and $\mathrm{CD} 25^{+} \mathrm{CD} 127^{-}$(d) within $\mathrm{CD} 4^{+} \mathrm{T}$ cell pool. Significant changes in relation to healthy controls indicated directly above specific group column; additional differences distinguished with lines. 
HCV-infected
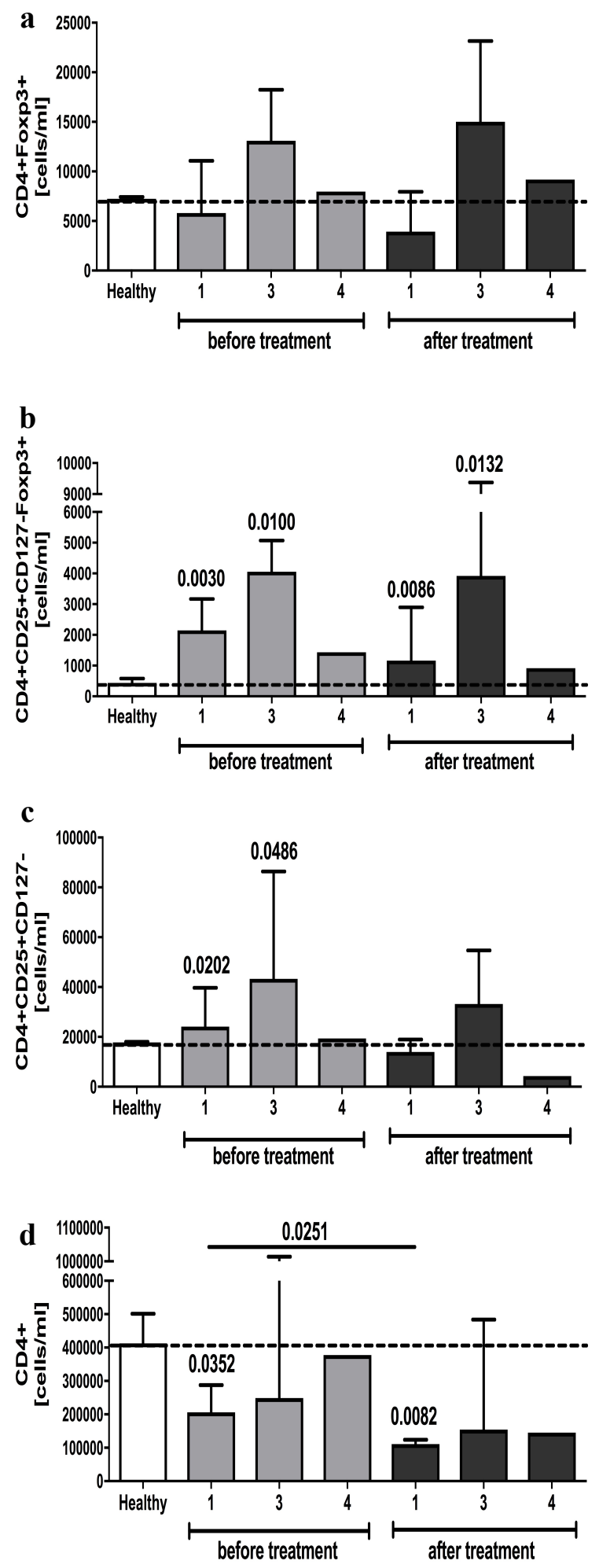

HCV/HIV-coinfected
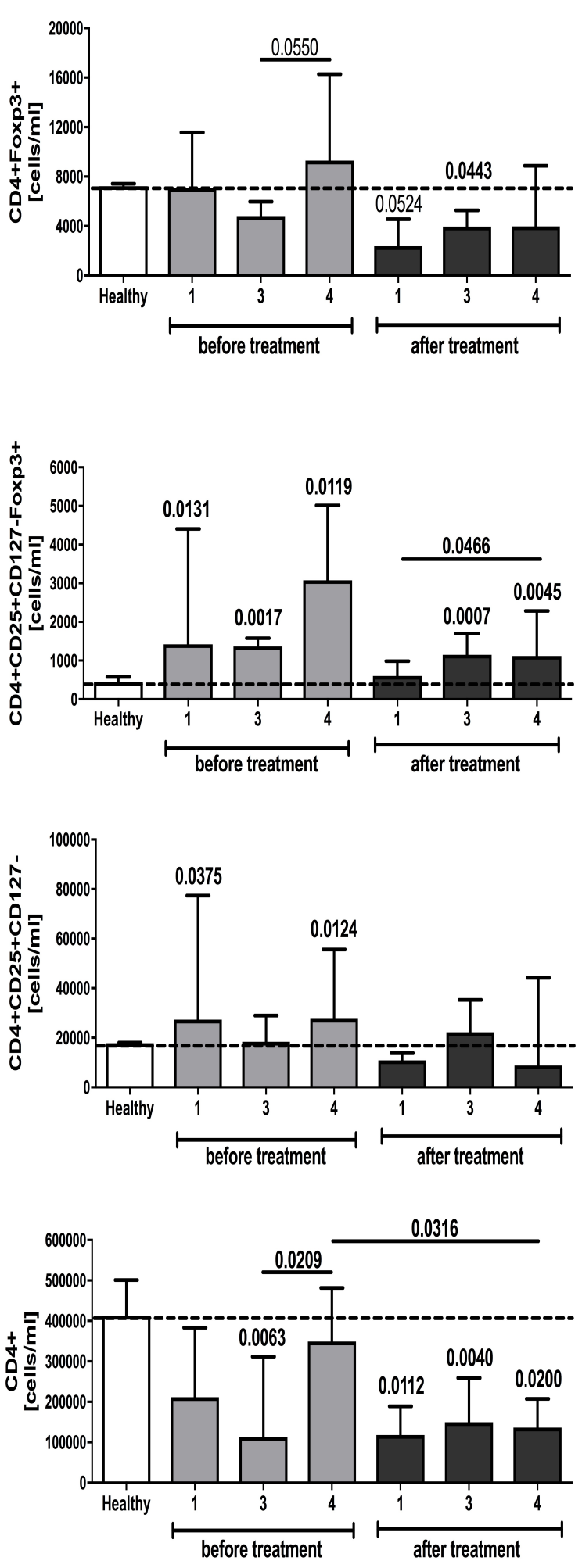

Figure 6. HCV virus genotype-related differences in regulatory T cells absolute numbers in response to anti-viral therapy in HCV-infected (left column) and HCV/HIV-coinfected patients (right column). Treg-related parameters in HCV or $\mathrm{HCV} / \mathrm{HIV}$-coinfected patients presented as absolute numbers: Foxp3 ${ }^{+}$(a), $\mathrm{CD}_{2} 5^{+} \mathrm{CD} 127^{-} \mathrm{Foxp}^{+}$(b), $\mathrm{CD}^{2} 5^{+} \mathrm{CD} 127^{-}$(c) $\mathrm{CD}^{+}$lymphocytes, and total $\mathrm{CD} 4^{+}$cells (d). Significant changes in relation to healthy controls indicated directly above specific group column; additional differences distinguished with lines connecting significantly different groups. 


\section{Discussion}

Recent data indicate that $\mathrm{HIV} / \mathrm{HCV}$-coinfection influences immune system activity during pegIFN- $\alpha / \mathrm{RBV}$ treatment by inducing higher $\mathrm{HCV}$-specific $\mathrm{T}$ cells responses in approaches aimed at reducing regulatory $\mathrm{T}$ cells activity [20]. Work by Rallon et al. indicated that the frequency of regulatory $\mathrm{CD}_{4}^{+} \mathrm{T}$ cells, namely, Foxp3 ${ }^{+}$and $\mathrm{CD} 25^{+} \mathrm{Foxp}^{+}$, was only increased in HIV-infected and HCV/HCV-coinfected patients [28]. Here, however, we have demonstrated using more precise immunophenotyping $\left(\mathrm{CD} 4^{+} \mathrm{CD} 25^{+} \mathrm{CD} 127^{-} \mathrm{Foxp}^{+}\right)$ methods and absolute number counts that increased values of $\mathrm{T}_{\text {regs }}$ are not limited to infection with HIV but are present in HCV-infected and HCV / HIV-coinfected patients as well. Our data are consistent with results that demonstrated higher levels of regulatory cells present in patients infected with HCV [29-31]. Similar to prior work indicating a lack of effect of HCV-coinfection on $\mathrm{T}_{\text {regs }}$ frequencies in HIV-infected individuals [13], we found no differences in regulatory $\mathrm{T}$ cells between $\mathrm{HCV}$-infected and $\mathrm{HCV} / \mathrm{HIV}$-coinfected patients. Interestingly, analysis of hepatic $\mathrm{T}_{\text {regs }}$ revealed higher numbers of these cells in patients with $\mathrm{HCV}$ monoinfection, suggesting a critical role of $\mathrm{T}$ cell imbalance in controlling excessive immune responses within tissues [32].

Here, we found that application of combined pegylated interferon and ribavirin (pegIFN- $\alpha /$ RBV) led to markedly higher frequencies of T cells, demonstrating a suppressive phenotype in HCV-infected patients, as opposed to the lack of treatment effects in $\mathrm{HCV} / \mathrm{HIV}$-coinfection. It is worth noting that such differences were not observed when analyzing absolute numbers of these cells. However, we demonstrated that the presence of $\mathrm{HIV}$ in $\mathrm{HCV}$-infected patients was associated with a significant decline in total regulatory $\mathrm{CD}^{+}{ }^{+} \mathrm{Foxp}^{+} \mathrm{T}$ cells in response to pegIFN- $\alpha / \mathrm{RBV}$ treatment. In addition, the decline in the proportion of regulatory T cells during HAART therapy, based on a less detailed analysis of $\mathrm{CD}^{+} \mathrm{CD} 25^{+} \mathrm{Foxp}^{+}$(without using the CD127 marker), was demonstrated in recent years [13]. Despite the presumed deleterious effects of $\mathrm{T}_{\text {reg }}$ activity in HIV and HCV infection $[18,33]$, it was found that in antiviral responses, these cells may exert favorable effects by suppressing excessive $\mathrm{T}$ cell activity and protecting against reinfection [34]. Therefore, the observed negative correlation between the absolute number of regulatory $\mathrm{CD} 4^{+} \mathrm{Foxp} 3^{+}$ cells and HCV viral load observed in the present study supports that hypothesis. Therefore, the increased $\mathrm{T}_{\text {regs }}$ frequency in HCV-infected and HCV/HIV-coinfected patients, even following treatment, may be regarded as a favorable effect in controlling activity of effector $\mathrm{T}$ cells and viremia. Further studies should investigate the role of $\mathrm{T}_{\text {regs }}$ in $\mathrm{HCV}$ and/or HIV infection and their ambiguous nature in antiviral responses.

As in prior studies by Rallon et al. [28], there was no observed correlation between regulatory $\mathrm{T}$ cells and activation status of $\mathrm{CD}^{+}$cells in patients with $\mathrm{HCV}$ alone and coinfected with HIV. However, as suggested recently [35], this does not exclude the possibility that depletion of $\mathrm{T}_{\text {regs }}$ may result in recovered responses of $\mathrm{T}$ cells affected by viral infection.

Despite the decreased number of regulatory $\mathrm{T}$ cells that may inhibit HCV-specific responses, we have found that pegIFN- $\alpha /$ RBV therapy significantly enhances the HIVinduced decline in absolute $\mathrm{CD}^{+} \mathrm{T}$ cells number. These observations are supported by prior work that shows a significant decline in the number of $\mathrm{CD} 4^{+} \mathrm{T}$ cells as a result of IFN- $\alpha / \mathrm{RBV}$ treatment in HIV-infected participants [36]. Therefore, we propose that pegIFN- $\alpha / \mathrm{RBV}$ treatment should be reconsidered in those with HCV/HIV co-infection. Interestingly, in recent years, an inverse correlation was found between $\mathrm{T}_{\text {reg }}$ frequency and $\mathrm{CD}^{+} \mathrm{T}$ cell counts in HIV-infected patients [13,37], and this was confirmed in our study amongst $\mathrm{HCV} / \mathrm{HIV}$-coinfected individuals. In addition, it is worth noting that previous studies have suggested an $\mathrm{HCV}$-induced, apoptosis-mediated decline in $\mathrm{CD} 4^{+} \mathrm{T}$ cells in $\mathrm{HCV} / \mathrm{HIV}$-coinfected patients [16]. Thus, further investigation is required to evaluate the exact role of $\mathrm{T}_{\text {reg }}$ in $\mathrm{HCV}$ and/or HIV infection to explain the pronounced decline in $\mathrm{CD}^{+} \mathrm{T}$ cells counts in response to pegIFN- $\alpha / \mathrm{RBV}$, despite the concomitant decrease in regulatory $\mathrm{T}$ cell numbers. 
We did not find any association between regulatory $\mathrm{T}$ cell counts and biochemical markers of liver damage, namely, AST, ALT, or GGT, in either studied group of patients; even in HCV-related liver dysfunction, despite the increased $\mathrm{T}_{\text {reg }}$ level, no such association has been found [38]. However, the significantly elevated APRI scores in HCV/HIVcoinfected patients correlated with $\mathrm{CD} 4^{+} \mathrm{CD} 25^{+} \mathrm{CD} 127^{-}$regulatory $\mathrm{T}$ cell counts, thus indicating an association between higher numbers of these cells and APRI-based predictions of hepatic fibrosis. This observation is consistent with prior data indicating elevated cell counts in HCV patients with HIV co-infection [39]. The analysis of regulatory T cells including the Foxp3 marker showed no correlation between Tregs and fibrosis-predicting factor (APRI), which is consistent with observations in the existing literature [14]. In addition, recent studies using mouse models indicate that depletion of cells with a regulatory phenotype may lead to liver fibrosis [21]. Moreover, patients with HCV/HIV-coinfection have been demonstrated to exhibit decreased numbers of hepatic Foxp $3^{+}$regulatory $\mathrm{T}$ cells in parallel with increased expansion of cytotoxic $\mathrm{CD} 8^{+}$cells when compared to individuals with HCV monoinfection [32]. Therefore, it is important to precisely evaluate the role of $\mathrm{T}_{\text {regs }}$ depending on their peripheral or tissue localization.

Previous data showed that increased values of Foxp $3^{+}$cells within $\mathrm{CD} 4{ }^{+} \mathrm{CD} 25^{+}$intrahepatic lymphocytes are associated with increased HCV viral load and accelerated disease progression [29,30]. Interestingly, in our study, a correlation between peripheral blood CD4 ${ }^{+} \mathrm{Foxp}^{+} \mathrm{T}_{\text {reg }}$ and HCV viral load was found in HCV-infected patients; this negative association was observed in $\mathrm{HCV} / \mathrm{HIV}$-coinfected patients in reference to putative $\mathrm{CD} 4^{+} \mathrm{CD} 25^{+} \mathrm{CD} 127^{-}$regulatory $\mathrm{T}$ cell absolute numbers. Thus, higher levels of putative Tregs might explain the lower HCV viral load present in blood of HCV/HIV-coinfected patients compared to those infected with $\mathrm{HCV}$ alone. In addition, the positive correlation of $\mathrm{CD}^{+} \mathrm{Foxp}^{+}$Tregs and HIV viral load in HCV/HIV-coinfected subjects supports the previously suggested hypothesis that HIV persistence might be supported by increased levels of cells with a regulatory phenotype [28]. In fact, Zhuang et al. also demonstrated a positive correlation between Tregs and HIV viral load in HIV-infected individuals [13]. In addition, it is worth noting that ribavirin alone is not singularly responsible for blocking $\mathrm{HCV}$ replication. Combination with pegIFN- $\alpha$ was demonstrated to enhance RBV effects even in in vitro conditions with no additional activity of the immune system involved [40]. Thus, the role of IFN- $\alpha$ as an essential element in the phenomenon observed in our study was justified. We agree with the previously suggested hypothesis that regulatory $\mathrm{T}$ cells may have two equally crucial roles in $\mathrm{HCV}$ infection: conferring virus persistence through suppression of effector $\mathrm{T}$ cells and prevention of excessive immunopathological reactions in intense antiviral responses [41].

Recent studies demonstrated that DAA reduces cytokines associated with liver damage, including pro-inflammatory TNF- $\alpha$, IL- $1 \beta$, and IL- 6 , with a concomitant decline in $\mathrm{HCV}$ viral load [42]. Interestingly, here we found that treatment implementing pegIFN$\alpha / \mathrm{RBV}$ induces higher levels of Tregs that also correlated positively with virus clearance. Therefore, it seems highly probable that DAA and pegIFN- $\alpha /$ RBV therapeutic regimens lead to similar immunological phenomenon involving participation of both proinflammatory and immunosuppresive factors. Regarding beneficial effects of DAA on liver function, in the course of anti-viral therapy reported by Sasaki et al. [42], despite an increase of Tregs after pegIFN- $\alpha$-based treatment, no association has been shown in reference to liver related parameters-ALT, AST, and APRI. In accordance with that, it seems crucial to carefully monitor immunological and virological aspects of the patients when choosing between DAA or pegIFN- $\alpha /$ RBV therapy to achieve the highest therapeutic efficacy.

Despite the shift from IFN-based to DAA therapeutic protocols, there are still numerous data suggesting beneficial effects of pegIFN- $\alpha / R B V$, especially in patients with HIV coinfection requiring such an approach. In accordance with data presented here, slight differences have been demonstrated in the achievement of a sustained viral response depending on the HCV genotype-the highest rates were obtained in types 1, 2, and 4 [43]. Interestingly, these genotype-related changes in Treg levels were not present in HCV-HIV- 
coinfected patients. We reported higher initial frequencies of Tregs in that group; however, it was not associated with a differential response to the treatment applied. Assuming that higher levels of Tregs in those with HCV genotype 3 in the course of pegIFN- $\alpha /$ RBV treatment contribute to the effective regulation of anti-viral responses, our data might support previously reported high SVR rates in these groups [44]. The demonstrated high efficacy of IFN- $\beta$ in type $3 \mathrm{HCV}$ (predominantly) was also evidence for the constant need of IFN-based approaches in certain groups of HCV-infected patients [45]. Cumulatively, in the world of DAA, there is still a place for interferons application in HCV therapy of certain patient groups, but only with well-established treatment selection criteria.

In summary, we found that the application of pegIFN- $\alpha / \mathrm{RBV}$ therapy in $\mathrm{HCV}$-infected patients was associated with the increased expansion of $T$ cells with a regulatory phenotype, with prolonged elevated levels of these cells in HCV/HIV-coinfected individuals. Our data indicate that regulatory $T$ cells may be a crucial component of the antiviral response, especially in HCV-infected patients. Considering the lack of change in regulatory Tcell phenotype and its correlation with HIV and HCV viral load, we presume that HIVcoinfection inhibits the expansion of Tregs in response to treatment in HCV/HIV-coinfected patients, therefore controlling virus persistence and HCV-related liver damage. However, further studies directed at regulatory T cells in HCV and/or HIV infection are needed to determine their specific role in the antiviral immune response.

Supplementary Materials: The following are available online at https:/ / www.mdpi.com/article/10 .3390/v13081448 / s1, Figures S1-S3; Table S1 and S2. Supplementery Figure S1: Gating strategy of regulatory T cells (Treg). Foxp3 ${ }^{+}$Tregs were evaluated on the basis of gating Foxp3-positive cells within $\mathrm{CD}^{+}$lymphocytes and $\mathrm{CD} 25^{+} \mathrm{CD} 127^{-}$cells (A). Delineation of positive signals for CD25 PE-Cy5, CD127 Alexa647 and Foxp3 PE was based on FMO (fluorescence-minus-one) and negative population controls (B). Supplementary Figure S2: Graphical presentation of the regulatory T cells data correlations with virological, biochemical and immunological data in HCV-infected patients prior treatment application. Treg-related parameters before (upper graphs) and after treatment (\% of after versus before; lower graphs) were analyzed. Statistically significant correlations were bolded in the table. Supplementary Figure S3: Graphical presentation of the regulatory T cells data correlations with virological, biochemical and immunological data in $\mathrm{HCV} / \mathrm{HIV}$-coinfected patients prior to treatment application. Treg-related parameters before (upper graphs) and after treatment ( $\%$ of after versus before; lower graphs) were analyzed. Statistically significant correlations were bolded in the table. Supplementary Table S1: Presentation of virological, biochemical and immunological data of healthy subjects, and HCV-infected and HCV/HIV-coinfected patients before treatment. Data presented as median values with 25th and 75th percentile in the brackets. Supplementary Table S2: Tabular presentation of regulatory T cells, T cell activation (CD25) and development-associated protein (CD127) results in healthy subjects, HCV-infected and HCV/HIV-coinfected patients (data presented as median values with 25th and 75th percentile in the brackets). Bolded values indicate differences between $\mathrm{HCV}$ - and $\mathrm{HCV} / \mathrm{HIV}$-infected groups (significantly compared to: a- $\mathrm{HCV}$ infected before treatment, $\mathrm{b}-\mathrm{HCV}$-infected after treatment, $\mathrm{c}-\mathrm{HCV} / \mathrm{HIV}$-infected before treatment, $\mathrm{d}-\mathrm{HCV} / \mathrm{HIV}$-infected after treatment).

Author Contributions: Conceptualization, A.G. and K.G.; methodology, K.G.; investigation, K.G., M.G., A.G., A.H.; resources, A.G., A.H.; writing-original draft preparation, A.G., K.G., A.H.; writing-review and editing, K.G., A.G., A.K.-G., M.M.; visualization, K.G.; supervision, M.M., R.F., K.G.; funding acquisition, M.M., A.G. All authors have read and agreed to the published version of the manuscript.

Funding: This research received no external funding.

Institutional Review Board Statement: The study was conducted according to the guidelines of the Declaration of Helsinki and approved by the Institutional Ethics Committee.

Informed Consent Statement: Informed consent was obtained from all subjects involved in the study.

Data Availability Statement: The data presented in this study are available on request from the corresponding author. The data are not publicly available due to privacy restrictions. 
Acknowledgments: We would like to thank Karolina Leziak for in-depth lingual correction of the manuscript.

Conflicts of Interest: The authors declare no conflict of interest.

\section{References}

1. Soriano, V.; Vispo, E.; Labarga, P.; Medrano, J.; Barreiro, P. Viral hepatitis and HIV co-infection. Antivir. Res. 2010, 85, 303-315. [CrossRef]

2. Daar, E.S.; Lynn, H.; Donfield, S.; Gomperts, E.; Hilgartner, M.W.; Hoots, W.K.; Chernoff, D.; Arkin, S.; Wong, W.Y.; Winkler, C.A. Relation between HIV-1 and hepatitis C viral load in patients with hemophilia. J. Acquir Immune Defic. Syndr. 2001, 26, 466-472. [CrossRef]

3. Martinez-Sierra, C.; Arizcorreta, A.; Díaz, F.; Roldán, R.; Martín-Herrera, L.; Pérez-Guzmán, E.; Girón-González, J.A. Progression of chronic hepatitis $C$ to liver fibrosis and cirrhosis in patients coinfected with hepatitis $C$ virus and human immunodeficiency virus. Clin. Infect. Dis. 2003, 36, 491-498. [CrossRef]

4. Merchante, N.; Girón-González, J.A.; González-Serrano, M.; Torre-Cisneros, J.; García-García, J.A.; Arizcorreta, A.; Ruiz-Morales, J.; Cano-Lliteras, P.; Lozano, F.; Martínez-Sierra, C.; et al. Survival and prognostic factors of HIV-infected patients with HCVrelated end-stage liver disease. Aids 2006, 20, 49-57. [CrossRef] [PubMed]

5. D'Arminio Monforte, A.; Cozzi-Lepri, A.; Castagna, A.; Antinori, A.; De Luca, A.; Mussini, C.; Caputo, S.L.; Arlotti, M.; Magnani, G.; Pellizzer, G.; et al. Risk of developing specific AIDS-defining illnesses in patients coinfected with HIV and hepatitis $C$ virus with or without liver cirrhosis. Clin. Infect. Dis. 2009, 49, 612-622. [CrossRef]

6. Hyrcza, M.D.; Kovacs, C.; Loutfy, M.; Halpenny, R.; Heisler, L.; Yang, S.; Wilkins, O.; Ostrowski, M.; Der, S.D. Distinct transcriptional profiles in ex vivo $\mathrm{CD}^{+}$and $\mathrm{CD} 8^{+} \mathrm{T}$ cells are established early in human immunodeficiency virus type 1 infection and are characterized by a chronic interferon response as well as extensive transcriptional changes in CD8 ${ }^{+} \mathrm{T}$ cells. J. Virol. 2007, 81, 3477-3486. [CrossRef]

7. Kovacs, A.; Al-Harthi, L.; Christensen, S.; Mack, W.; Cohen, M.; Landay, A. CD8(+) T cell activation in women coinfected with human immunodeficiency virus type 1 and hepatitis C virus. J. Infect. Dis. 2008, 197, 1402-1407. [CrossRef] [PubMed]

8. Balasubramanian, A.; Groopman, J.; Ganju, R. Underlying pathophysiology of HCV infection in HIV-positive drug users. J. Addict. Dis. 2008, 27, 75-82. [CrossRef] [PubMed]

9. Billerbeck, E.; Thimme, R. CD8 ${ }^{+}$regulatory T cells in persistent human viral infections. Hum. Immunol. 2008, 69, 771-775. [CrossRef]

10. Baecher-Allan, C.; Viglietta, V.; Hafler, D. Human CD4 ${ }^{+} \mathrm{CD} 25^{+}$regulatory T cells. Semin. Immunol. 2004, 16, 89-97. [CrossRef]

11. Dittmer, U.; He, H.; Messer, R.J.; Schimmer, S.; Olbrich, A.R.; Ohlen, C.; Greenberg, P.D.; Stromnes, I.M.; Iwashiro, M.; Sakaguchi, S.; et al. Functional impairment of CD8(+) T cells by regulatory T cells during persistent retroviral infection. Immunity 2004, 20, 293-303. [CrossRef]

12. Boasso, A.; Vaccari, M.; Hryniewicz, A.; Fuchs, D.; Nacsa, J.; Cecchinato, V.; Andersson, J.; Franchini, G.; Shearer, G.M.; Chougnet, C. Regulatory T-cell markers, indoleamine 2,3-dioxygenase, and virus levels in spleen and gut during progressive simian immunodeficiency virus infection. J. Virol. 2007, 81, 11593-11603. [CrossRef]

13. Zhuang, Y.; Wei, X.; Li, Y.; Zhao, K.; Zhang, J.; Kang, W.; Sun, Y. HCV coinfection does not alter the frequency of regulatory T cells or $\mathrm{CD}^{+} \mathrm{T}$ cell immune activation in chronically infected HIV+ Chinese subjects. AIDS Res. Hum. Retroviruses 2012, 28, $1044-1051$. [CrossRef]

14. Hartling, H.J.; Gaardbo, J.C.; Ronit, A.; Knudsen, L.S.; Ullum, H.; Vainer, B.; Clausen, M.R.; Skogstrand, K.; Gerstoft, J.; Nielsen, S.D. $\mathrm{CD}^{+}$and $\mathrm{CD}^{+}$regulatory $\mathrm{T}$ cells (Tregs) are elevated and display an active phenotype in patients with chronic HCV mono-infection and HIV/HCV co-infection. Scand. J. Immunol. 2012, 76, 294-305. [CrossRef]

15. Cho, H.; Kikuchi, M.; Li, Y.; Nakamoto, N.; Amorosa, V.K.; Valiga, M.E.; Chang, K.M. Induction of Multiple Immune Regulatory Pathways with Differential Impact in HCV/HIV Coinfection. Front. Immunol. 2014, 5, 265. [CrossRef] [PubMed]

16. Körner, C.; Krämer, B.; Schulte, D.; Coenen, M.; Mauss, S.; Fätkenheuer, G.; Oldenburg, J.; Nattermann, J.; Rockstroh, J.K.; Spengler, U. Effects of HCV co-infection on apoptosis of CD4 ${ }^{+}$T-cells in HIV-positive patients. Clin. Sci. 2009, 116, 861-870. [CrossRef]

17. Potter, M.; Odueyungbo, A.; Yang, H.; Saeed, S.; Klein, M. Study CC-iC. Impact of hepatitis C viral replication on CD4(+) T-lymphocyte progression in HIV-HCV coinfection before and after antiretroviral therapy. Aids 2010, 24, 1857-1865. [CrossRef] [PubMed]

18. Weiss, L.; Donkova-Petrini, V.; Caccavelli, L.; Balbo, M.; Carbonneil, C.; Levy, Y. Human immunodeficiency virus-driven expansion of CD4(+)CD25(+) regulatory T cells, which suppress HIV-specific CD4 T-cell responses in HIV-infected patients. Blood 2004, 104, 3249-3256. [CrossRef] [PubMed]

19. Sugimoto, K.; Ikeda, F.; Stadanlick, J.; Nunes, F.; Alter, H.; Chang, K. Suppression of HCV-specific T cells without differential hierarchy demonstrated ex vivo in persistent HCV infection. Hepatology 2003, 38, 1437-1448. [CrossRef]

20. Alatrakchi, N.; Graham, C.; van der Vliet, H.; Sherman, K.; Exley, M.; Koziel, M. Hepatitis C virus (HCV)-specific CD8(+) cells produce transforming growth factor beta that can suppress HCV-specific T-cell responses. J. Virol. 2007, 81, 5882-5892. [CrossRef] [PubMed] 
21. Nunoya, J.; Washburn, M.; Kovalev, G.; Su, L. Regulatory T Cells Prevent Liver Fibrosis during HIV Type 1 Infection in a Humanized Mouse Model. J. Infect. Dis. 2014, 209, 1039-1044. [CrossRef]

22. Liu, W.; Putnam, A.L.; Xu-Yu, Z.; Szot, G.L.; Lee, M.R.; Zhu, S.; Gottlieb, P.A.; Kapranov, P.; Gingeras, T.R.; Fazekas de St Groth, B.; et al. CD127 expression inversely correlates with FoxP3 and suppressive function of human CD4 ${ }^{+}$T reg cells. J. Exp. Med. 2006, 203, 1701-1711. [CrossRef] [PubMed]

23. Shevyrev, D.; Tereshchenko, V. Treg Heterogeneity, Function, and Homeostasis. Front. Immunol. 2019, 10, 3100. [CrossRef]

24. Sherif, Z.A.; Nouraie, M.; Begum, R.; Afsari, A.; Shokrani, B.; Lee, E.; Laiyemo, A.O.; Brim, H.; Ashktorab, H. Factors influencing treatment outcome in hepatitis $\mathrm{C}$ virus minority patients at an inner-city hospital: A STROBE-complaint article. Medicine 2020, 99, e19505. [CrossRef]

25. Irshad, M.; Gupta, P.; Irshad, K. Molecular targeting of antiviral drugs used against hepatitis C virus infection. Hepatoma Res. 2018, 4, 23. [CrossRef]

26. Hesamizadeh, K.; Tavakoli, A.; Nikbin, M. Peg-interferon Plus Ribavirin Combination Therapy in HCV Mono-infected and HCV /HIV Co-infected Patients in Iran. Med. J. Islam Repub. Iran 2019, 33, 63. [CrossRef]

27. Ghany, M.; Strader, D.; Thomas, D.; Seeff, L. Diagnosis, Management, and Treatment of Hepatitis C: An Update. Hepatology 2009, 49, 1335-1374. [CrossRef]

28. Rallón, N.I.; López, M.; Soriano, V.; García-Samaniego, J.; Romero, M.; Labarga, P.; García-Gasco, P.; González-Lahoz, J.; Benito, J.M. Level, phenotype and activation status of $\mathrm{CD}^{+}{ }^{+} \mathrm{Foxp}^{+}$regulatory $\mathrm{T}$ cells in patients chronically infected with human immunodeficiency virus and/or hepatitis C virus. Clin. Exp. Immunol. 2009, 155, 35-43. [CrossRef] [PubMed]

29. Franceschini, D.; Paroli, M.; Francavilla, V.; Videtta, M.; Morrone, S.; Labbadia, G.; Cerino, A.; Mondelli, M.U.; Barnaba, V. PD-L1 negatively regulates $\mathrm{CD} 4^{+} \mathrm{CD} 25^{+}$Foxp3 $3^{+}$Tregs by limiting STAT- 5 phosphorylation in patients chronically infected with HCV. J. Clin. Investig. 2009, 119, 551-564. [CrossRef] [PubMed]

30. Cabrera, R.; Tu, Z.; Xu, Y.; Firpi, R.J.; Rosen, H.R.; Liu, C.; Nelson, D.R. An immunomodulatory role for CD4(+)CD25(+) regulatory T lymphocytes in hepatitis C virus infection. Hepatology 2004, 40, 1062-1071. [CrossRef] [PubMed]

31. Ebinuma, H.; Nakamoto, N.; Li, Y.; Price, D.A.; Gostick, E.; Levine, B.L.; Tobias, J.; Kwok, W.W.; Chang, K.M. Identification and in vitro expansion of functional antigen-specific CD25+ Foxp $3^{+}$regulatory T cells in hepatitis C virus infection. J. Virol. 2008, 82, 5043-5053. [CrossRef] [PubMed]

32. Williams, S.K.; Donaldson, E.; Van der Kleij, T.; Dixon, L.; Fisher, M.; Tibble, J.; Gilleece, Y.; Klenerman, P.; Banham, A.H.; Howard, M.; et al. Quantification of hepatic Foxp3 ${ }^{+}$T-lymphocytes in HIV/hepatitis C coinfection. J. Viral. Hepat. 2014, 21, 251-259. [CrossRef]

33. Boettler, T.; Spangenberg, H.C.; Neumann-Haefelin, C.; Panther, E.; Urbani, S.; Ferrari, C.; Blum, H.E.; von Weizsäcker, F.; Thimme, R. T cells with a CD4 $4^{+} \mathrm{CD} 25^{+}$regulatory phenotype suppress in vitro proliferation of virus-specific $\mathrm{CD} 8^{+} \mathrm{T}$ cells during chronic hepatitis C virus infection. J. Virol. 2005, 79, 7860-7867. [CrossRef] [PubMed]

34. Kinter, A.L.; Hennessey, M.; Bell, A.; Kern, S.; Lin, Y.; Daucher, M.; Planta, M.; McGlaughlin, M.; Jackson, R.; Ziegler, S.F.; et al $\mathrm{CD} 25(+) \mathrm{CD} 4(+)$ regulatory $\mathrm{T}$ cells from the peripheral blood of asymptomatic HIV-infected individuals regulate CD4(+) and CD8(+) HIV-specific T cell immune responses in vitro and are associated with favorable clinical markers of disease status. J. Exp. Med. 2004, 200, 331-343. [CrossRef] [PubMed]

35. Dietze, K.; Zelinskyy, G.; Liu, J.; Kretzmer, F.; Schimmer, S.; Dittmer, U. Combining Regulatory T Cell Depletion and Inhibitory Receptor Blockade Improves Reactivation of Exhausted Virus-Specific CD8(+) T Cells and Efficiently Reduces Chronic Retroviral Loads. PLoS Pathog. 2013, 9, e1003798. [CrossRef]

36. Pillai, S.K.; Abdel-Mohsen, M.; Guatelli, J.; Skasko, M.; Monto, A.; Fujimoto, K.; Yukl, S.; Greene, W.C.; Kovari, H.; Rauch, A.; et al. Role of retroviral restriction factors in the interferon- $\alpha$-mediated suppression of HIV-1 in vivo. Proc. Natl. Acad. Sci. USA 2012, 109, 3035-3040. [CrossRef]

37. Tsunemi, S.; Iwasaki, T.; Imado, T.; Higasa, S.; Kakishita, E.; Shirasaka, T.; Sano, H. Relationship of CD4 ${ }^{+} \mathrm{CD} 25^{+}$regulatory T cells to immune status in HIV-infected patients. Aids 2005, 19, 879-886. [CrossRef] [PubMed]

38. Yoshizawa, K.; Abe, H.; Kubo, Y.; Kitahara, T.; Aizawa, R.; Matsuoka, M.; Aizawa, Y. Expansion of CD4(+)CD25(+)FoxP3(+) regulatory $\mathrm{T}$ cells in hepatitis $\mathrm{C}$ virus-related chronic hepatitis, cirrhosis and hepatocellular carcinoma. Hepatol. Res. 2010, 40, 179-187. [CrossRef]

39. Vali, B.; Jones, R.B.; Sakhdari, A.; Sheth, P.M.; Clayton, K.; Yue, F.Y.; Gyenes, G.; Wong, D.; Klein, M.B.; Saeed, S.; et al. HCV-specific $\mathrm{T}$ cells in $\mathrm{HCV} / \mathrm{HIV}$ co-infection show elevated frequencies of dual Tim-3/PD-1 expression that correlate with liver disease progression. Eur. J. Immunol. 2010, 40, 2493-2505. [CrossRef]

40. Kanda, T.; Yokosuka, O.; Imazeki, F.; Tanaka, M.; Shino, Y.; Shimada, H.; Tomonaga, T.; Nomura, F.; Nagao, K.; Ochiai, T.; et al. Inhibition of subgenomic hepatitis C virus RNA in Huh-7 cells: Ribavirin induces mutagenesis in HCV RNA. J. Viral. Hepat. 2004, 11, 479-487. [CrossRef]

41. Bolacchi, F.; Sinistro, A.; Ciaprini, C.; Demin, F.; Capozzi, M.; Carducci, F.C.; Drapeau, C.M.; Rocchi, G.; Bergamini, A. Increased hepatitis $\mathrm{C}$ virus $(\mathrm{HCV})$-specific $\mathrm{CD}^{+} \mathrm{CD} 25^{+}$regulatory $\mathrm{T}$ lymphocytes and reduced $\mathrm{HCV}$-specific $\mathrm{CD} 4^{+} \mathrm{T}$ cell response in HCV-infected patients with normal versus abnormal alanine aminotransferase levels. Clin. Exp. Immunol. 2006, 144, 188-196. [CrossRef] [PubMed]

42. Sasaki, R.; Meyer, K.; Moriyama, M.; Kato, N.; Yokosuka, O.; Ray, R.B.; Aurora, R.; Ray, R.; Kanda, T. Rapid hepatitis C virus clearance by antivirals correlates with immune status of infected patients. J. Med. Virol. 2019, 91, 411-418. [CrossRef] [PubMed] 
43. Nelson, M.; Rubio, R.; Lazzarin, A.; Romanova, S.; Luetkemeyer, A.; Conway, B.; Molina, J.M.; Xu, D.; Srinivasan, S.; Portsmouth, S. Safety and Efficacy of Pegylated Interferon Lambda, Ribavirin, and Daclatasvir in HCV and HIV-Coinfected Patients. J. Interferon. Cytokine Res. 2017, 37, 103-111. [CrossRef] [PubMed]

44. Dalgard, O.; Bjøro, K.; Hellum, K.B.; Myrvang, B.; Ritland, S.; Skaug, K.; Raknerud, N.; Bell, H. Treatment with pegylated interferon and ribavarin in HCV infection with genotype 2 or 3 for 14 weeks: A pilot study. Hepatology 2004, 40, $1260-1265$. [CrossRef] [PubMed]

45. Sasaki, R.; Kanda, T.; Nakamoto, S.; Haga, Y.; Nakamura, M.; Yasui, S.; Jiang, X.; Wu, S.; Arai, M.; Yokosuka, O. Natural interferon-beta treatment for patients with chronic hepatitis C in Japan. World J. Hepatol. 2015, 7, 1125-1132. [CrossRef] 